УДК [-028.42:174.7]

DOI: https://doi.org/10.35387/ucj.1(1).2020.69-72

\title{
OLENA TRYNUS
}

\section{ACADEMIC INTEGRITY: CHALLENGES OF MODERNITY}

Abstract. In recent years, the Ukrainian academic and educational community has been addressing issues of academic integrity and the implementation of international academic standards. In the civilized academic world, a fundamental role attaches to the fundamental values of academic integrity as an effective instrument for the quality of education ensuring, the moral and ethical image of a modern educator and scientist formation, the creation of a highly competitive society. In the article the essence of the concept "academic integrity" in modern discourse is revealed, and its components are presented. The European experience in counteracting of academic fraud has been analyzed; its most widely used methods are outlined. It has been found that there is no ideal way of counteracting academic abuse in the world; standardized procedures for assessing the educational policy of academic institutions regarding academic integrity have not been developed. The information on the SAIUP project (Strengthening Academic Integrity in Ukraine Project), which was launched in Ukraine to promote academic integrity, has been submitted. The scientific policy of the Ivan Ziaziun Institute of Pedagogical Education and Adult Education for preventing manifestations of academic unfairness is described, as well as the introduction of a system of measures to avoid manifestations of academic plagiarism and self-plagiarism, citation errors, and practice of falsification of scientific research. It is concluded that the views of the academic community on the problems of academic integrity depend to a large extent on the state policy and definition of the system of social values and ethical norms by educational and scientific institutions. The proposals on adherence to academic integrity in Ukraine on the state and institutional levels are substantiated.

Key words: academic integrity, values of academic integrity, academic unfairness, plagiarism, selfplagiarism, falsification, reference, citation.

\section{АКАДЕМІЧНА ДОБРОЧЕСНІСТЬ: ВИКЛИКИ СУЧАСНОСТІ}

Анотація. Останні роки українська наукова і освітня спільнота звертається до питань академічної доброчесності та впровадження міжнародних академічних стандартів. У цивілізованому академічному світі велика роль відводиться фундаментальним цінностям академічної доброчесності як дієвому інструменту забезпечення якості освіти, формування морально-етичного образу сучасного освітянина і науковця, як наслідок - створення висококонкурентного суспільства. У статті розкрито сутність поняття «академічна доброчесність» у сучасному дискурсі, подано ї̈ складники. Проаналізовано європейський досвід протидії академічному шахрайству, окреслено ії найпоширеніші методи. З'ясовано, що у світі відсутній ідеальний спосіб протидії академічним зловживанням, не розроблені стандартизовані процедури оцінки політики освітніх закладів щодо академічної доброчесності. Подано інформацію про проект SAIUP (Srtengthening Academic Integrity in Ukraine Project), який розпочато в Украӥні з метою сприяння академічній доброчесності. Охарактеризовано наукову політику Інституту педагогічної освіти і освіти дорослих імені Івана Зязюна щодо запобігання проявів академічної недоброчесності, а також запровадження системи заходів щодо уникнення проявів академічного плагіату та самоплагіату, помилок цитування, практики фальсифікації наукових досліджень. Зроблено висновок про те, що погляди академічної спільноти на проблеми академічної доброчесності значною мірою залежать від визначення державою, освітніми закладами, науковими установами системи суспільних цінностей, етичних норм. Обгрунтовано пропозиції щодо дотримання академічної доброчесності в Україні на державному та інституалізаційному рівнях.

Ключові слова: академічна доброчесність, цінності академічної доброчесності, академічна нечесність, плагіат, самоплагіат, фальсифікація, посилання, цитування.

Introduction. An important task of educational and scientific institutions, the modern transformations in Ukraine is to formation of professional and scientific elites, ensure a high level of education quality, recognition of the Ukrainian scientific and increase the global reputation and rating of pedagogical qualification staff on the world 
level. In the context of this abstract, the fundamental role lies in the implementation of international academic standards, the creation of a new academic ethos and the respect for the fundamental values of Academic Integrity.

The aim of the study. Determination of the phenomenon essence "Academic Integrity", consider the study of national and foreign experience in preventing academic dishonesty.

Theoretical framework and research methods. In recent years, the theme of Academic Integrity has gone from complete novelty to recognition by the educational and scientific community. This is evidenced by the adoption of main legislative acts (Laws of Ukraine - "On Higher Education" (2014), "On Education" (2017), Guidelines for higher education institutions in support of the principles of Academic Integrity (2018), Order of Scientific Degree (2013), Recommendations for the Prevention of Academic Plagiarism and its Detection in Scientific Works (2018) Regulations on the National Academic Text Repository (2017), etc.; Academic Integrity has been considerd a lot of scientists, as: A.Artiukhov, V. Bakhrushyn, Y. Holovachova, R. Grimes, J. Carroll, T. Lichman, E. Nikolaev, V. Satsyk, E. Studnyi, T. Finikov, T. Fishman, V. Khmarskyi, T. Yavorska, etc., which examines the essence of this category, describes the types of academic dishonesty and determines the factors that cause it, outlines ways to respond to such cases. Results of international dissemination of plagiarism studies, ident?fication of factors that determine academic fraud has been presented by McCabe, Trevino \& Butterfield (1999), Magnus, Polterovich, Danilov, \& Savvateev (2002), Grimes (2004), Teixeira (2013), Impact of Policies for Plagiarism in Higher Education Across Europe (2010-2013, etc.). Among the methods we use in research are: analysis, generalization, systematization of literature on the problem of research, ideas of national and foreign experience in observing the norms of academic integrity.

Results. The first interpretation of the term "Academic Integrity" has been presented in the Law of Ukraine "On Education" as a set of ethical principles and rules defined by the law, which should be guided by the participants of the educational process while studying, teaching and conducting scientific (creative) activities for the purpose of ensuring confidence in learning outcomes and / or scientific creative achievements (Law of Ukraine "On Education", 2017). This means that the activities of educational institutions, scientific institutions should be determined by the principles of academic integrity (honesty, trust, justice, respect, responsibility, etc.), avoiding manifestations of academic dishonesty (fraud, academic plagiarism, cheating, writing off, bribery, etc.).

Academic Integrity is an interdisciplinary category that combines the moral and human conduct rules in the educational and scientific environment and the mechanisms and tools through which they are put into practice. Ability to work honestly, responsibly, develop critical thinking, tolerate the thoughts of others - these are the components of Academic Integrity and characteristics of a competent educator and scholar.

One of the most dangerous manifestations of academic dishonesty is the phenomenon of academic plagiarism. The main features are: lack of correct links; self-plagiarism, reproducing without reference of own previously published texts; citation errors (lack of quotation marks, incorrect link design, etc.); falsification of data, which is the deliberate modification of certain data to confirm the scientific findings of the researcher (Guidelines for Institutions, 2018). All of these cases are in violation of academic ethics because they are inconvenient to others and may violate their rights.

Instruments for preventing academic integrity violations are defined as: indep?ndent performance of educational tasks, tasks of current and final control of learning outcomes; references to sources of infor?ation when using ideas, statements, information; compliance with copyright law; providing reliable information on the results of their own educational (scientific, creative) activity (Law of Ukraine "On Education", 2017). The formation of academic integrity culture in the educational and scientific space of Ukraine requires the hard work of the academic community and cannot emerge at once.

The analysis of European experience (Austria, United Kingdom, Germany, Sweden) on academic dishonesty prevention methods, shows, that these countries has approaches to understanding the nature of plagiarism 
(plagiarism as moral action, plagiarism as an institutional blunder, plagiarism as a component of the educational process). They have created special tools for minimizing of academic dishonesty (for example, estab?ishing the Office of Independent Arbitration (England and Wales); special programs developing and implementing higher education institutions for institutional policies to prevent plagiarism; also, investigate internal causes and current global practices in the field of plagiarism and promoting the culture of plagiarism, etc.) (Satsyk, 2017).

It should be noted that no country has an ideal way of counteracting academic abuse, and there are no standardized procedures for evaluating academic integrity policies. In no EU country, with the exception of Sweden, academic plagiarism is regulated by law, and the possibility of independent resolution of the problem is conditioned by public confidence in European universities (Nikolaev, 2018).

According to international researches, Ukraine is the world leader in cases of academic dishonesty. According to E. Nikolaev (2018) the problem of academic dishonesty in Ukraine is emphasized quantitatively (our country is the "world leader" in the percentage of write-offs, the number of diplomas and theses written to order), but not too different qualitatively from those encountered by the academic community in Europe.

We agree with V. Satsyk's (2017) opinion that today it is an unfortunate impression that academic integrity in our country is perceived mainly as some mythical concept that can be talked about, rather than as an effective tool for ensuring the quality of education, achieving a high level of scientific research. Unfortunately, non-observance of ethical principles by some members of the academic community negates the results of the selfless work of many others and leads to a lack of confidence in the honest results of their activities. The more students, teachers, scholars will violate Academic Integrity, the less trust will be given to all educators and scholars, even if they do not personally violate anything.

In order to promote academic integrity in Ukraine, the Srtengthening Academic Integrity in Ukraine Project (SAIUP), launched in 2018, implemented by the American Councils for
International Education with the Ministry of Education and Science of Ukraine. The aim of project - to use common USA and Ukrainian experience to develop and implement a fouryear action plan to familiarize academic, research and teaching staff, students with the practical value and importance of academic integrity. The mission of the Project is to form a new academic culture based on trust, honesty, transparency, real learning, genuine scientific and research work.

Long-term experience in scientific insti?ution (Ivan Ziazun Institute of Pedagogical and Adult Education of the National Academy of Educational Sciences of Ukraine) certifies that adherence of academic integrity principles by researchers and graduates is a leading factor in its effective functioning and development. This contributes to ensuring the quality of the performed research, obtaining important for science and practice results, contributes to the quality of training and certification of highly qualified personnel, as a consequence - to increase public confidence in science and scientists, to secure their reputation in Ukraine and the world.

According to the results of an anonymous survey of academic degrees applicants at the Institute and their scientific leaders regarding problems with observance of academic integrity, it was found that:

1) such problems do not exist $(20 \%$ of respondents); such problems exist (63\% of respondents); academic integrity is identified only with the prevention of plagiarism, the presence of textual matches without proper references (17\% of respondents);

2) causes of academic integrity violation such as: general crisis of society; legal nihilism; the lack of a comprehensive regulatory framework for academic integrity and the imposition of sanctions on researchers exposed in plagiarism; science detachment from the needs of society, the labor market, the world scientific community; demotivation of scientists in adherence to the principles of academic integrity in the context of low salaries, lack of a state request for research results; lack of up-to-date and summarized information on this issue and an ideal way to counteract academic abuse;

3 ) the most important components of academic integrity in the conditions of scientific institution activity, such as: 
avoidance of academic plagiarism manif?stations as self-plagiarism, errors of citation, practice of scientific researches falsification.

In order to overcome the academic integrity manifestations as plagiarism and self-plagiarism at the Ivan Ziaziun Institute of Pedagogical and Adult Education of the National Academy of Educational Sciences of Ukraine has been implemented a system of measures to prevent the research staff integrity, for example: scientific institution support of the academic integrity honesty policy; high qualification for all research staff in modern academic writing and text editing; scientific papers of employees and graduates are accompanied by a document on the absence of plagiarism, with an external review prepared by a specialist; hold the special requirements of conventional citation styles; all scientific publications need to upload into the e-Library of NAES of Ukraine; academic writing courses for young scientists and $\mathrm{PhD}$ students.

Conclusions. Therefore, one of the main forming of modern Ukrainian society is understanding the need to respect the principles of academic integrity; implement systematic measures to counteract fraud. The views of the academic community on the problems of academic integrity depend on the determination of the State, educational and scientific institutions of the system of public values, ethical standards. We believe that some proposals for academic integrity in Ukraine need to be made.

At the state level: to create educational legislative acts on the regulation of academic abuse, plagiarism, responsibility for violation of academic integrity; establishing information collection on academic malpractice cases; creation of the National Repository of Academic Texts; Improvement of antiplagiarism program systems.

At the level of higher education institution (scientific institution): create an atmosphere of academic integrity; develop normative documents on academic integrity; to study and introduce foreign experience in ensuring academic integrity; develop academic integrity modules, teach academic writing and research methods, etc.

Prospects for further research are to study the problems of promoting the values of academic integrity in Ukraine, to develop tools to prevent plagiarism in dissertation works.

\section{REFERENCES}

Law of Ukraine: On Higher Education 1556-VII. (2014). URL: https://zakon.rada.gov.ua/laws/show/1556-

Law $\frac{18}{\text { of }}$ Ukraine: On Copyright and Related Rights 3792-XII. (1994). URL: https://zakon.rada.gov.ua/laws/show/3792-12

Law of Ukraine: On Education 2145-VIII. (2017). URL: https://zakon.rada.gov.ua/laws/show/2145-19

Ministry of Education and Science of Ukraine. (2018). Guidelines for higher education institutions in support of the academic integrity principles. URL: https://mon.gov.ua/storage/app/media/ vishchaosvita/2018/10/25/recomendatsii.pdf

Nikolaiev, Ye. (2018). How to promote the values of academic integrity in Ukrainian universities? URL: https://www.skeptic.in.ua/promoting-integrity/

Satsyk, V. (2017). Academic Integrity: mythical concept or effective tool for quality assurance in higher education? URL: http://education-ua.org/ua/articles/930-akademichna-dobrochesnist-mifichnakontseptsiya-chi-dievij-instrument-zabezpechennya-yakosti-vishchoji-osviti

Finikov, T., \& Artiukhova, A. (2016). Academic honesty as a basis for the university's sustainable devel?pment. Kyiv: Takson.

Олена Тринус, кандидат педагогічних наук, старший дослідник, учений секретар Інституту педагогічної освіти і освіти дорослих імені Івана Зязюна НАПН України.

Olena Trynus, PhD in Pedagogy, Senior Researcher Research Staff Secretary of Ivan Ziaziun Institute of Pedagogical and Adult Education of NAES of Ukraine. 